\title{
The Effect of Vitamin D3 on Skeletal Muscle in Rat after Ischemia Reperfusion Injury: Preliminary Report
}

\section{Sıçan İskelet Kasında İskemi Reperfüzyon Hasarı Sonrası Vitamin D3'ün Etkisi: Ön Çalışma}

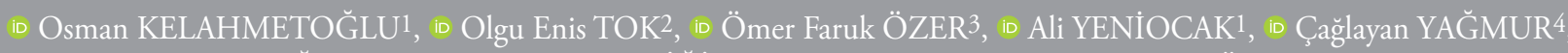

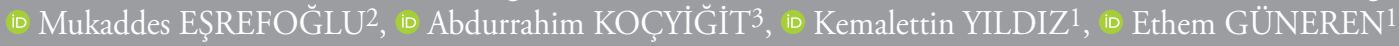 \\ ${ }^{1}$ Bezmialem Vakıf University Faculty of Medicine, Department of Plastic, Reconstructive and Aesthetic Surgery, İstanbul, Turkey \\ ${ }^{2}$ Bezmialem Vakıf University Faculty of Medicine, Department of Histology and Embryology, İstanbul, Turkey \\ ${ }_{3}^{3}$ Bezmialem Vakıf University Faculty of Medicine, Department of Biochemistry, İstanbul, Turkey \\ ${ }^{4}$ Private Practic, Samsun, Turkey
}

\section{ABSTRACT}

Objective: Vitamin D is a vitamin that has gained popularity in recent years and has an anti-inflammatory and immunmodular effect. In the literature review we conducted, there was no study investigating the effect of vitamin D to prevent ischemia reperfusion (I/R) injury in skeletal muscle. The aim of this study was to investigate the effect of vitamin D on skeletal muscle in I/R injury.

Methods: Six rats were used in each group including ischemia group (group I) and experimental group (group D given vitamin D). In the histopathological examination, inflammation and apoptosis levels were studied in gastrocnemius muscle. In biochemical analysis, total oxidative stress and total antioxidant and catalase levels were evaluated in anterior tibialis muscle.

Results: The number of apoptotic cells in group D were found significantly lower than group I. In the terms of total antioxidants and catalase levels, there were significant difference between group $\mathrm{D}$ and group I.

Conclusion: Our results support the hypothesis that vitamin D is an agent that can be used to prevent I/R injury.

Keywords: Vitamin D, ischemia-reperfusion injury, skeletal muscle
ÖZ

Amaç: Vitamin D, son yıllarda giderek popülarite kazanan ve antienflamatuvar ve immünomodülatör etkiye sahip bir vitamindir. Yaptığımız literatür taramasında iskelet kasında iskemi reperfüzyon (İ/R) hasarını önlemeye yönelik vitamin D'nin etkisini inceleyen bir çalışma bulunamamıştır. Çalışmamızda; iskemi reperfüzyon hasarında vitamin D'nin iskelet kası üzerindeki etkisinin araştırılması amaçlanmıştır.

Yöntemler: İskemi grubu ve deney grubu (D vitamin verilen) olmak üzere her grupta 6 adet, toplam 12 adet sıçan kullanılmıştır. Histopatolojik incelemede gastroknemius kasında enflamasyon, apopitozis düzeyi araştırıldı. Biyokimsayal analizde ise anterior tibialis kasında total oksidatif stres, total antioksidan ve katalaz seviyelerine bakıldı.

Bulgular: Apoptotik hücre sayısının, D vitamin uygulanan grupta kontrol grubuna göre anlamlı olarak daha az olduğunu saptandı. Katalaz ve total antioksidan seviyeleri açısından Grup D ve Grup I arasında anlamlı fark saptanmıştır.

Sonuç: Bu çalışmada iskelet kası İ/R hasarına vitamin D’nin olumlu yönde etki gösterdiği saptanmıştır.

Anahtar Sözcükler: Vitamin D, iskemi-reperfüzyon hasarı, iskelet kasi
Address for Correspondence: Osman KELAHMETOǦLU, Bezmialem Vakıf University Faculty of Medicine, Department of Plastic, Reconstructive and Aesthetic Surgery, İstanbul, Turkey E-mail: osmankelahmetoglu@gmail.com ORCID ID: orcid.org/0000-0002-6651-2872

Cite this article as: Kelahmetoğlu O, Tok OE, Özer ÖF, Yeniocak A, Yağmur Ç, Eşrefoğlu M, Koçyiğit A, Yıldız K, Güneren E. The Effect of Vitamin D3 on Skeletal Muscle in Rat after Ischemia Reperfusion Injury: Preliminary Report. Bezmialem Science 2020;8(3):233-8.

${ }^{0}$ Copyright 2020 by the Bezmiâlem Vakıf University

Bezmiâlem Science published by Galenos Publishing House.
Received: 25.06.2019

Accepted: 05.11.2019 


\section{Introduction}

In reconstructive surgery, flaps are used to repair complex tissue defects due to trauma or tumor ablation. Despite surgical and technical advances, flap losses are still an ongoing clinical problem. One of the most important causes of this loss is ischemia reperfusion (I/R) injury. Therefore, experimental and clinical studies are ongoing to increase flap survival in plastic surgery (1-3). Numerous agents have been used experimentally to reduce the effects of $I / R$ injury (4). Vitamin $D$, on the other hand, is a vitamin that has role especially bone metabolism and has anti-inflammatory and immunomodulatory effects, and its other effects have been investigated in recent years. In particular, its effect on recovery after muscle damage has been shown. In the literature review we conducted, no study investigating the effect of vitamin $D$ to prevent $I / R$ injury in skeletal muscle was found. The purpose of this study was to investigate the effect of vitamin D on skeletal muscle after I/R injury.

\section{Method}

\section{Group Selection}

This study was approved by Bezmialem Vakıf University Animal Care and Use Committee with the decision number 2015126 and all protocols were carried out in accordance with the National Institute of Health Guidelines for the Care and Use of Laboratory Animals. In the study, a total of 12 Sprague-Dawley genus 280-370 g female rats, 6 in each group, were used with a: $95 \%$ and b: $80 \%$ confidence level. Rats were obtained from Bezmialem Vakıf University Animal Center and randomly divided into two groups. Rats were fed with standard feed and care was provided in accordance with day and night rhythm.

\section{Experiment Protocol}

Rats were divided into two groups as $n=6$. Ketamine hydrochloride $(35 \mathrm{mg} / \mathrm{kg} \mathrm{IM})$ and xylazine hydrochloride $(5 \mathrm{mg} / \mathrm{kg} \mathrm{IM})$ were applied as anesthetic to 6 rats in Group I (ischemia group). A $4.6 \mathrm{~mm} \times 390 \mathrm{~mm}$ plastic clamp tourniquet (Würth', Gaisbach, Germany) was applied to right back limb of the rat and tightened until distal pulses could not be obtained and pale leg was observed. Blood flow ceased for 4 hours. After the ischemia, the blood flow was restarted and for the next 7 days, intraperitoneal $0.05 \mathrm{~mL}$ of saline was injected. The left posterior extremities of the rats in the ischemia group in which ischemia was not created were named as Group C (control group). In Group D (experimental group) tourniquet was applied to right posterior extremity of 6 rats and blood flow was cut for 4 hours. Blood flow after ischemia was started again for the next 7 days and intraperitoneal 0.5 $\mathrm{mg} / \mathrm{kg} /$ day vitamin D3 (Devita-3, Deva, İstanbul, Turkey) was injected. The left posterior limbs of the rats in the experimental group without ischemia were named as Group DC. The rats in both groups were given ketamine hydrochloride $(35 \mathrm{mg} / \mathrm{kg} \mathrm{IM})$ and xylazine hydrochloride $(5 \mathrm{mg} / \mathrm{kg} \mathrm{IM})$ as anesthetic after 7 days. Both posterior limb gastrocnemius and anterior tibialis muscles to be used in the examination were taken. The animals were then sacrificed using ether anesthesia. In histopathological examination, inflammation in the gastrocnemius muscle and apoptosis level (Tunel method), and total oxidative stress and total antioxidant levels in the anterior tibialis muscle were examined.

\section{Histological Examination}

For histological examination, the gastrocnemius muscle was completely taken and fixed in 10\% neutral buffered formalin for 72 hours. Tissues were dehydrated by passing through rising alcohol series $(70 \%, 90 \%, 96 \%, 100 \%)$, made transparent with xylene, kept in $60{ }^{\circ} \mathrm{C}$ paraffin overnight and embedded in paraffin. Sections prepared $5 \mu \mathrm{m}$ thick from paraffin blocks were stained with Hematoxylin-Eosin (H\&E) stain for morphological evaluation. Stained sections were examined and viewed with Nikon Eclipse i5 (Tokyo, Japan) light microscope with Nikon DS-Filc (Tokyo, Japan) camera attachment and NIS Elements version 4.0 image analysis system (Nikon Instruments Inc, Tokyo, Japan).

\section{TUNEL Method}

It is the labelling of apopitotic cells in situ. Five $\mu \mathrm{m}$ thick sections taken on the positive charged slides were deparaffinized with xylene, passed through the descending alcohol series, rehydrated and washed with PBS. The TUNEL method was performed according to the method in the user manual provided by the manufacturer (Apoptag Plus Peroxidase In situ apoptosis Kit, Chemicon International, S7101). The sections taken were kept in Proteinase K ( $20 \mu \mathrm{g} / \mathrm{mL}$, Sigma) for 15 minutes. After washing with distilled water, the sections were left in 3\% hydrogen peroxide prepared in PBS for 5 minutes, washed with PBS and left for 30 minutes in equilibration buffer. Then all sections were kept in $37^{\circ} \mathrm{C}$ oven for 1 hour with terminal deoxynucleotidyl transferase (TdT) enzyme and incubated for 10 minutes at room temperature in wash buffer. After washing 3 times for 1 minute in PBS, it was kept in the anti-digoxigenin conjugate for 30 minutes. It was washed 4 times in PBS with each for 2 minutes. It was washed 4 times in PBS for 2 minutes each. After the sections were kept in peroxidase substrate for 6 minutes for staining, they were washed 3 times for 1 minute each in distilled water, stained with Mayer Hematoxylin and closed with entellan. TUNEL positive cells were counted on images taken at x200 magnification in 5 similar areas randomly selected by shifting the preparation clockwise in each section.

\section{Biochemical Analysis}

\section{Measurement of Catalase Activity (CAT)}

Catalase is one of the antioxidant enzymes that neutralize free oxygen radicals after I/R injury. Skeletal muscle CAT activity was determined using the colorimetric method described by Goth in which $\mathrm{H}_{2} \mathrm{O}_{2}$ substrate was incubated, and the enzymatic reaction was stopped by the addition of ammonium molybdate. The density of the yellow complex formed by molybdate and $\mathrm{H}_{2} \mathrm{O}_{2}$ was measured at $405 \mathrm{~nm}$.

\section{Measurement of Total Antioxidant Status (TAS)}

The TAS value of the supernatant fractions was determined using a new automatic measurement method developed by Erel 
(5). In this method, hydroxyl radicals, the strongest biological radicals, are produced. In the experiment, the ferrous ion solution contained in Reagent 1 is mixed with the hydrogen peroxide present in Reagent 2. Later produced radicals, like brown dianicidinyl radical cations produced by hydroxyl radicals, are also strong radicals. Using this method, the antioxidative effect of the sample is measured against weak radical reactions initiated by the hydroxyl radicals produced.

The analysis has excellent sensitivity values which are less than $3 \%$. The results are expressed in the "nmol Trolox Equiv./mg protein" unit.

\section{Measurement of Total Oxidant Status}

The total oxidant status (TOS) value of the supernatant fractions was determined using a new automated measurement method developed by Erel (6). The oxidants present in the sample oxidize the iron ion-odianidine complex to the ferric ion. The oxidation reaction is enhanced by glycerol molecules that are abundant in the reaction medium. The iron ion makes a colored complex with xylenol orange in an acidic environment. The color density, which can be measured spectrophotometrically, is related to the total amount of oxidant molecules in the sample. The analysis is calibrated with hydrogen peroxide and the results are expressed in "nmol $\mathrm{H}_{2} \mathrm{O}_{2}$ Equiv./mg protein" unit.

\section{Statistical Analysis}

Statistical analysis was done using Graph-Pad Prism 5.0 (GraphPad Software, San Diego, CA, USA) program. One-Way ANOVA method and Tukey test were used for statistical analysis. $\mathrm{p}<0.05$ was considered significant. $\left({ }^{*}\right): \mathrm{p}<0.05,\left({ }^{*}\right): \mathrm{p}<0.01$, $\left.{ }^{(* *}\right): \mathrm{p}<0.001$ and $\left({ }^{* * * *}\right): \mathrm{p}<0.0001$ (Table 1 ).

\section{Results}

TUNEL positive labelled cells were not found in muscle tissue in Group C and Group DC, which were extremities without ischemia (Figure $1 \mathrm{~A}, \mathrm{~B}$ ). A large number of TUNEL positive labelled cells were observed to be dark brown in Group I (Figure 1C). It was observed that the number of TUNEL positive labelled cells in Group D was lower compared to Group I (Figure 1D). While the number of apoptotic cells was $1 \pm 0.4$ in Group C, it was $1 \pm 0.3$ in Group DC, $159 \pm 6$ in Group I and $147 \pm 5$ in Group D. Compared to Group C and DC, the number of apoptotic cells increased significantly in Group I and Group D
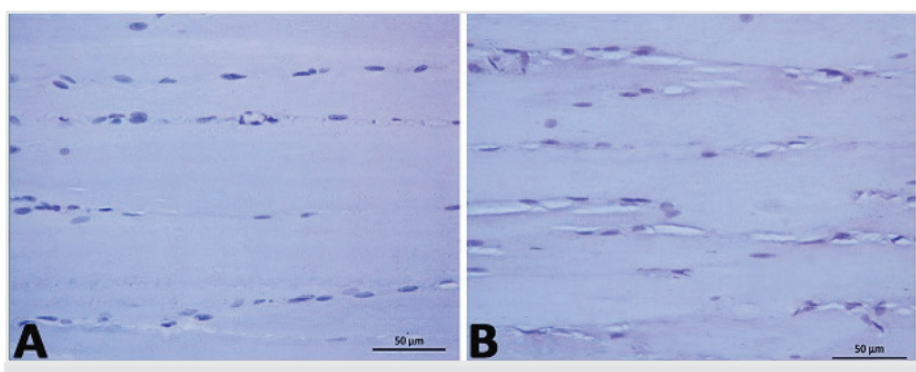

( $<<0.0001)$. Compared to Group I $(159 \pm 6)$, a significant decrease was observed in Group D (147士5) (Table 2). When examined in terms of CAT, enzyme level was significantly increased in group D $(21.17 \pm 10.83)$ compared to group I $(0.18 \pm 0.02)(\mathrm{p}<0.0001)$.

Table 1. $p<0.05$ was considered significant. $(*): p<0.05$, (**): $p<0.01,(* * *): p<0.001$ and $(* * * *): p<0.0001$

\section{Catalase}

\begin{tabular}{l|l|l}
$\begin{array}{l}\text { Tukey's multiple } \\
\text { comparisons test } \\
\text { Group C vs. Group I }\end{array}$ & Significance & p value \\
$\begin{array}{l}\text { Group I vs. Group D } \\
\text { TAS }\end{array}$ & $* * *$ & 0.0206 \\
\hline $\begin{array}{l}\text { Tukey's multiple } \\
\text { comparisons test }\end{array}$ & Significance & p value \\
$\begin{array}{l}\text { Group C vs. Group D } \\
\text { Group DC vs. Group D }\end{array}$ & $*$ & 0.0004 \\
\hline $\begin{array}{l}\text { Group I vs. Group D } \\
\text { ToS }\end{array}$ & $* *$ & 0.02531 \\
\hline $\begin{array}{l}\text { Tukey's multiple } \\
\text { comparisons test } \\
\text { Group C vs. Group I }\end{array}$ & * & 0.0092 \\
\hline
\end{tabular}

TAS: Total antioxidant status, TOS: Total oxidant status, $\left(^{*}\right): p<0.05$, $(* *): p<0.01,(* * *): p<0.001$ and $(* * * *): p<0.0001$

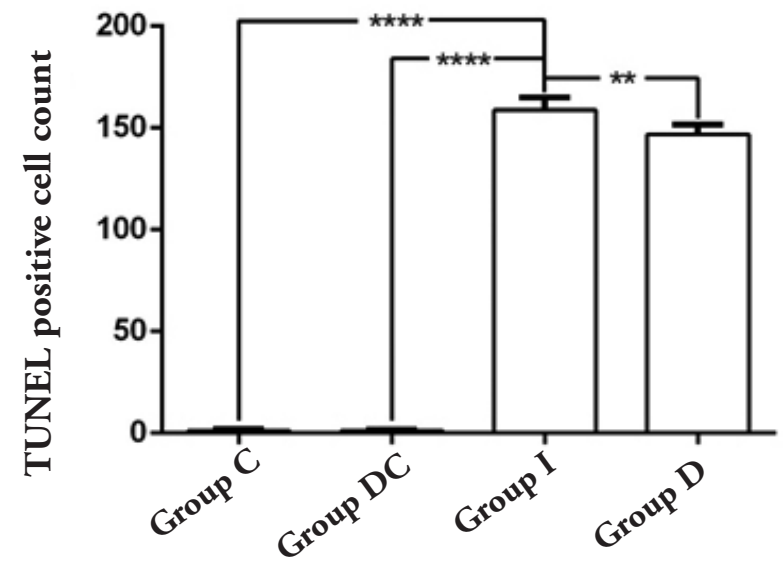

Table 2. Graph of TUNEL positive cells with statistical analysis between groups

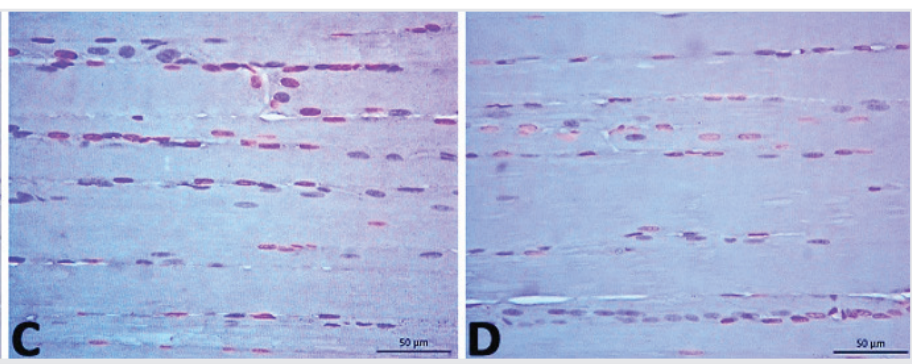

Figure 1. Preparations stained by TUNEL method. There are no TUNEL positive cells in Group C (A) and DC (B). There are many positive stained cells in Group I (C). With the increase in the number of positive stained cells in Group D, fewer stained TUNEL positive cells are seen compared to Group I 
When examined in terms of TAS, a significant difference was found between group D $(0.33 \pm 0.24)$ and group I $(7.2 \pm 2.89)$ $(\mathrm{p}<0.01)$. When examined in terms of TOS, no significant difference was found between group D $(9.94 \pm 3.61)$ and group I $(7.29 \pm 2.34)(\mathrm{p}>0.05)$.

\section{Discussion}

Vitamin D is an oil-soluble vitamin that is taken orally and absorbed from the intestines and synthesized by the skin with the effect of the sun. The liver converts circulating vitamin $\mathrm{D}$ into 25 -hydroxycholecalciferol $[25(\mathrm{OH}) \mathrm{D} 2]$. This prehormone is then metabolized by the kidneys into the active form of vitamin $\mathrm{D}$ (1 alpha, 25 dihydroxyvitamin D [1.25 (OH) D2]). Although there is evidence that vitamin D has effects on myogenesis, muscle function and muscle strength, its effect on the injured muscle is largely unknown (7).

The I/R injury occurs when tissues restore molecular oxygen after ischemia. It can occur as a result of broad spectrum vascular events such as transplantation, thrombolytic therapy, limb trauma and cardiovascular surgery. If the ischemic tissue is as large as the legs, I/R injury may not only be local, but also may involve distant organs. It may affect organs such as skeletal muscle and cause death $(3,8)$. Reactive oxygen radicals and metabolites are formed as a result of chemotactic stimuli. During reperfusion, inflammatory mediators are produced by ischemic tissues, and this causes leukocyte migration and adhesion. As a result, endothelial damage and impaired microvascular integrity; causes edema, thrombosis and tissue necrosis (1). Numerous studies have been done to reduce I/R injury with small molecules, proteins, cytokines, and drugs (1-4). It has been claimed that antioxidants such as vitamins $\mathrm{A}, \mathrm{C}$ or $\mathrm{E}$ and selenium increase endogenous oxidative defenses to prevent cellular injury mediated by reactive oxygen species $(1,2)$. Use of plasma rich platelet has been found to be beneficial in the skin flap I/R injury model in mice (2).

This level of exposure is also associated with factors such as energy demand of tissue. The tissue with the least tolerance to ischemia in all extremity tissues is skeletal muscle ( 4 hours). Nerve tissue can withstand ischemia for 8 hours, adipose tissue 13 hours, skin 24 hours, and bone tissue for 4 days (9). Especially in plastic surgery routine, ischemic conditions can be seen in tissues after replantations, free and pedicled flap surgery. Skeletal muscle is the most susceptible tissue to ischemia and I/R injury effects can occur more quickly and severely. As a result of ischemia, injury begins and this injury increases with reperfusion paradoxically, and muscle and other tissues are affected by this injury. Antioxidant enzymes such as CAT (catalase), SOD (superoxide dismutase) and glutathione peroxidase are produced as defense mechanisms against ROS molecules. Oxidant and antioxidant activities balance themselves in all physiological processes. Disruption of this balance towards pro-oxidant activity causes dangerous damage to functional tissues and organs. Free radicals attack polyunsaturated fatty acids in the cell membrane, but antioxidants prevent and stop free radical activity against lipid peroxidation. Free radicals can change the biological structure and property of molecules such as proteins, lipids, carbohydrates, and DNA. Antioxidants can remove oxygen-derived radicals by delaying the peroxidation process of polyunsaturated fatty acids. As a result, the human body can be protected against injury due to free radicals and reactive oxygen species (ROS)by antioxidants (3). The use of antioxidant substances, hesperidin and ellargic acid, has been observed to have positive antioxidant effects on induced skeletal muscle I/R injury in rats (3). It has been shown that colchicine significantly reduces levels of malondialdehyde, tumor necrosis factor-alpha and interleukin-1 beta (IL-1 $\beta$ ), and that increases SOD activity in injured muscle tissues, and that reduces peroxidation and inflammatory cytokine levels in skeletal muscle I/R injury created in rats (10).

The efficacy of many antioxidants that reduce or prevent I/R injury has been demonstrated by experimental animal studies. Melatonin (11), vitamin E, superoxide dismutase, catalase, mannitol, allopurinol, iron chelating compounds, angiotensin converting enzyme inhibitors, calcium channel antagonists, $\mathrm{N}$-acetylcysteine are some of them (12). Vitamins, including A, $\mathrm{C}, \mathrm{D}$ and $\mathrm{E}$, have been found valuable in preventing $\mathrm{I} / \mathrm{R}$ injury, especially in clinical and animal models. Vitamins reduce the damage caused by superoxide, the most common free radical, by protecting the enzyme superoxide dismutase. Among them, 1,25 dihydroxyvitamin D3 (vitamin D3) has also been investigated. These studies have shown that vitamin D3 inhibits in vitro production of IL-6, increases regulator T cells and their immune tolerance (13).

While vitamin $\mathrm{D}$ is most often associated with bone growth and healing, new studies have identified a much broader spectrum of activity. Vitamin D deficiency has been associated with metabolic changes, oxidative stress and fibrosis. There are promising studies that vitamin $\mathrm{D}$ treatment increases regeneration in injured muscles. It has been shown to promote cardioprotection after myocardial infarction with anti-inflammatory, anti-fibrotic and antiapoptotic mechanisms (14). It has been shown that it is a supportive agent in the treatment of hepatocellular carcinoma and that it improves I/R injury in the lungs, kidneys and muscles $(15,16)$. There is limited knowledge about the effect of vitamin $\mathrm{D}$ on local and distant tissue damage and systemic inflammation after I/R injury (13).

Vitamin D affects intracellular regulatory phosphates by clinging to its receptors in skeletal muscle cells and maintaining cellular proliferation and differentiation. In muscle biopsies taken from people with low vitamin values, it was observed that muscle tissues were more atrophic (17). A significant relationship was found between rotator cuff muscle tears and vitamin D level (17). Shih et al. (13) Showed that local muscle edema was decreased with vitamin D3 treatment in the rat model, where they investigated the effect of lung and muscle damage after ischemia created by clamping bilateral femoral vessels; however in that study, the mechanism of inhibition of local tissue damage could not be demonstrated. That study differs from our study due to the administration of vitamin D before I/R injury (13).

In previous studies, vitamin $\mathrm{D}$ levels were not measured before administration and were given systemically $(13,15-17)$. 
The dose of vitamin D in our study was adjusted in accordance with the method Shih et al. (13) previously used while investigating the effects of $\mathrm{I} / \mathrm{R}$ injury on skeletal muscle.

Although there is a consensus that vitamin D is beneficial, its effects on muscle regeneration and whether it induces cellular response against ischemia are unknown, and this issue is still controversial. Vitamin D has been found to show anti-apoptotic properties for injured muscle tissue by increasing the level of insulin-like growth factor-1 (7).

The fact that CAT enzyme level and TAS value were higher in the vitamin $\mathrm{D}$ group was interpreted as vitamin $\mathrm{D}$ increased the protective mechanism of action. We believe that the lower levels of apoptotic cells in the group given vitamin D supports the biochemical result and indicates that fewer cells are affected. We consider the low number of subjects in the groups as one of the weaknesses of this study. Although the difference between the two groups is statistically significant, we think that it should be correlated with the studies with higher number of subjects. It supports our hypothesis that vitamin $\mathrm{D}$ is an agent that can be used to limit the effects of I/R injury.

As a result, in this study, it was determined that vitamin D had a positive effect on skeletal muscle I/R injury. We believe that there is a need for new studies with groups that have a higher number of subjects in terms of duration and dose adjustment and have been subjected to ischemia for different periods.

\section{Ethics}

Ethics Committee Approval: Bezmialem Vakıf University Animal Care and Use Committee with the decision number 2015- 126.

Informed Consent: No need for experimental work.

Peer-review: Externally peer reviewed.

\section{Authorship Contributions}

Concept: O.K., A.Y., Ç.Y., Design: O.K., O.E.T., Ö.F.Ö., Data Collection or Processing: O.K., O.E.T., Ö.F.Ö., M.E., A.K., Analysis or Interpretation: O.K., A.Y., E.G., O.E.T., Ö.F.Ö., Ç.Y., Literature Search: O.K., A.Y., K.Y., Writing: O.K., A.Y., K.Y.

Conflict of Interest: No conflict of interest was declared by the authors.

Financial Disclosure: This study was supported by the Scientific Research Projects Unit of Bezmialem Vakif University with support number 6.2015/ 14.

\section{References}

1. Tenekeci G, Bilen BT, Turkoz Y, Sahin N, Bulam N, Erdemli ME. The Effect of Selenium on Ischemia-Reperfusion Injury: An Experimental Study on Transverse Rectus Abdominis Musculocutaneous Flap Model. J Craniofac Surg 2016;27:242-6.

2. Rah DK, Min HJ, Kim YW, Cheon YW. Effect of Platelet-Rich Plasma on Ischemia-Reperfusion Injury in a Skin Flap Mouse Model. Int J Med Sci 2017;14:829-39.
3. Ekinci Akdemir FN, Gülçin İ, Karagöz B, Soslu R, Alwasel SH. A comparative study on the antioxidant effects of hesperidin and ellagic acid against skeletal muscle ischemia/reperfusion injury. J Enzyme Inhib Med Chem 2016;31(Suppl 4):114-8.

4. Kelahmetoglu O, Demir R, Okten G, Demir A, Alpaslan Pinarli F, Diraman E. The effect of mesenchymal stem cells and sildenafil on flap viability in perforator-based flaps for ischemia/reperfusion injury: An experimental study. Microsurgery 2016;36:402-9.

5. Erel O. A novel automated method to measure total antioxidant response against potent free radical reactions. Clin Biochem 2004;37:112-9.

6. Erel O. A new automated colorimetric method for measuring total oxidant status. Clin Biochem 2005;38:1103-11.

7. Stratos I, Li Z, Herlyn P, Rotter R, Behrendt AK, Mittlmeier T, et al. Vitamin D increases cellular turnover and functionally restores the skeletal muscle after crush in rats. Am J Pathol 2013;182:895-904.

8. Elmali N, Esenkaya I, Karadağ N, Taş F, Elmali N. Effects of resveratrol on skeletal muscle in ischemia-reperfusion injury. Ulus Travma Acil Cerrahi Derg 2007;13:274-80.

9. Ashrafzadeh Takhtfooladi M, Ashrafzadeh Takhtfooladi H, Sedaghatfar H, Shabani S. Effect of low-level laser therapy on lung injury induced by hindlimb ischemia reperfusion in rats. Lasers Med Sci 2015;30:1757-62.

10. Wang L, Shan Y, Chen L, Lin B, Xiong X, Lin L, et al. Colchicine protects rat skeletal muscle from ischemia reperfusion injury by suppressing oxidative stress and inflammation. Iran J Basic Med Sci 2016;19:670-5.

11. Sezgin G, Oztürk G, Güney S, Sinanoğlu O, Tunçdemir M. Protective effect of melatonin and 1,25-dihydroxyvitamin D3 on renal ischemia-reperfusion injuryin rats. Ren Fail 2013;35:374-9.

12. Takhtfooladi MA, Jahanshahi G, Jahanshahi A, Sotoudeh A, Samiee Amlashi O, Allahverdi A. Effects of $\mathrm{N}$-acetylcysteine on liver remote injury after skeletal muscle ischemia reperfusion in rats. Turk J Gastroenterol 2014;25(Suppl 1):43-7.

13. Shih PK, Chen YC, Huang YC, Chang YT, Chen JX, Cheng CM. Pretreatment of Vitamin D3 Ameliorates Lung and Muscle Injury Induced by Reperfusion of Bilateral Femoral Vessels in a Rat Model. J Surg Res 2011;171:323-8.

14. Sen F, Yilmaz S, Balci KG, Sen Ö, Gül M, Çay S, et al. The relationship between vitamin $\mathrm{D}$ levels and saphenous vein graft patency. Coron Artery Dis 2015;26:328-32.

15. Seif AA, Abdelwahed DM. Vitamin D ameliorates hepatic ischemic/ reperfusion injury in rats. J Physiol Biochem 2014;70:659-66.

16. de Bragança AC, Volpini RA, Canale D, Gonçalves JG, Shimizu $\mathrm{MH}$, Sanches TR, et al. Vitamin D deficiency aggravates ischemic acute kidney injury in rats. Physiol Rep 2015;3:e12331.

17. Angeline ME, Ma R, Pascual-Garrido C, Voigt C, Deng XH, Warren $\mathrm{RF}$, et al. Effect of diet-induced vitamin $\mathrm{D}$ deficiency on rotator cuff healing in a rat model. Am J Sports Med 2014;42:27-34. 